\title{
Rola architektury w rozwoju enoturystyki
}

\section{Role of architecture in the development of enotourism}

\begin{abstract}
Streszczenie
Enoturystyka to jedna z najszybciej rozwijających gałęzi turystyki w ostatnich latach. Ważnym aspektem turystyki winiarskiej jest fakt, że branża ta nastawiona jest na świadomego odbiorcę, dlatego istotne jest, aby ośrodki winiarskie miały odpowiednio przygotowane zaplecze i funkcjonalność umożliwiające turystom zgłębianie wiedzy i możliwość obserwacji produkcji wina na każdym jej etapie. Celem artykułu jest wskazanie ścisłej zależności między przebiegiem procesu projektowego i jakością architektury winnicy a rozwojem turystyki winiarskiej.
\end{abstract}

\section{Abstract}

Enotourism is one of the fastest growing branches of tourism in recent years. An important aspect of wine tourism is that the industry is geared towards a conscious consumer, so it is important that wine centers have adequate facilities and functionality to enable tourists to explore the knowledge and ability to observe wine production at every stage. The aim of the article is to indicate the close relationship between the course of the design process and the quality of the vineyard architecture and the development of wine tourism.

Słowa kluczowe: enoturystyka, turystyka winiarska, rozwój turystyki, winnica, architektura Keywords: enoturism, wine tourism, tourism development, vineyard, architecture

\section{Wstęp}

Enoturystyka (z geckiego oinos - wino) to jedna z gałęzi turystyki związana z podróżowaniem do miejsc związanych z produkcją wina (winnic, przetwórni, a także całych gospodarstw winiarskich) oraz z organizacją różnorodnych wydarzeń o takim profilu: święta winiarskie, prezentacje i degustacje win, winobrania. Ważnym aspektem turystyki winiarskiej jest fakt, że branża ta nastawiona jest na świadomego odbiorcę, który docenia walory kulturowe i edukacyjne takiego wyjazdu lub imprezy. Oferty kierowane są do osób, które zaineresowane są winem, jego historią, procesem produkcji, a nie tylko jego konsumpcją [1], [2]. Dlatego ważne jest, aby ośrodki winiarskie miały odpowiednio przygotowane zaplecze i funkcjonalność umożliwiające turystom zgłębianie wiedzy i możliwość obserwacji procesu produkcji wina od sadzenia winorośli aż po odkorkowania butelki.

\section{Enoturystyka}

\subsection{Profil enoturysty}

Aby dobrze zaprojektować ośrodek turystyczny i przygotować odpowiednią ofertę, należy poznać profil odbiorcy oraz jego motywy do podróżowania. Na podstawie badań prowadzonych w kilku krajach określono, że statystyczny enotury-

\section{Introduction}

Enotourism (Greek: oinos - wine) is one of branches of tourism connected with travelling to places related to the wine production (vineyards, processing plants, as well as entire wineries) and with the organisation of all sorts of events of such a profile: wine festivals, wine presentations and tastings, grape harvests. An important aspect of wine tourism is the fact that this industry is addressed to an informed customer, who appreciates cultural and educational values of such trips or events. Offers are directed to persons who are interested in wine, its history, its production process, and not merely in its consumption [1,2]. Therefore, it is important for wineries to administer properly prepared facilities and functionalities, allowing tourists to fathom relevant knowledge and offering them an opportunity to observe the wine production process, from planting vine to opening a bottle of wine.

\section{Enotourism}

\subsection{Enotourist's Profile}

So as to design a tourist centre well and to prepare an appropriate offer, it is necessary to get to know the profile of the recipients and their travelling motives. On the basis of research carried out in 
sta, to osoba o wyższych niż przeciętne dochodach, pracująza tym idzie, $w$ wieku ponad 25 lat, zwykle w przedziale $35-45$ lat. Podróżują najcześciej pary lub samotni mężczyźni, a wyjazdy mają zazwyczaj charakter krótkich wypadów weekendowych lub dłuższych wakacji, podczas których odwiedzaja kilka miejsc. Enoturyści zatrzymuja sie głównie w hotelach lub pensjonatach o dobrym standardzie, a oprócz gtównej atrakcii czyli samej winnicy interesuje ich także loka na kuchnia oraz kultura regionu. Glówna motywacja do turystyki winiarsiej jest chęc pozn Gia nowych win, mozl twosc ich degustacij i zakupu dkrywanie lokany

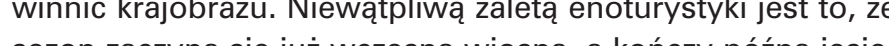
nią, co daje właścicielom winnic całoroczny równomierny nią, co daje
dochód [3].

Pod względem ekonomicznym, ważnym aspektem rozwoju turystyki winiarskiej jest rozwój sprzedaży bezpośredniej. Według statystyk nawet $75 \%$ osob odwiedzających winnicę kupuje na miejscu co najmniej jedną buterkę wina lub innych lokalnych produktow z nim związanych, a około $15 \%$ osób dokonuje takiego zakupu ponownie przy kolejnej wizycie lub korzystając ze sprzedaży wysyłkowej. Koszt butelki w sprzedaży detalicznej u producenta nie rożni się od kosztu tej samej butelki w sklepie czy markecie, lecz w pierwszym przypadku producent może zarobić nawet dwukrotnie więcej, omijając marże dla pośredników oraz inne wydatki związane z dystrybucją [3]

Oprócz wysokiej jakości i różnorodności dostępnych produktów oraz atrakcyjnego położenia ośrodka wymagający klient, a takimi są enoturyści, zwraca także uwagę na inne aspekty jakimi są estetyka gospodarstwa, dobre warunki sanitarne, a także jakość architektury podkreślającej dziedzictwo kulturowe regionu oraz niepowtarzalny klimat miejsca tworzony przez wystrój, oświetlenie, muzykę i zapach [4].

2.2. Historia i rozwój enoturystyki na świecie

Enoturystyka to relatywnie nowa gałęź turystyki. Podczas gdy inne formy wypoczynku, jak wyjazdy na plażę, do spa czy w góry towarzyszą nam od ponad stu lat, enoturystyka rozwinęła się dopiero $w$ latach 70 . XX wieku w Stanach Zjednoczonych. Faktem jest, że już wcześniej europejskie winnice przyjmowały gości, lecz celem wizyty był jedynie zakup wina bez powiązania ze zwiedzaniem samej winnicy, regionu i poznawania tajników produkcji.

Pierwotnym modelem były działania podjęte w 1975 roku w Napa Valley w Kalifornii. Założono tam stowarzyszenie zrzeszające lokalnych producentów wina, które miało na celu promocję wina i miejsc, gdzie jest ono wytwarzane jako atrakcji turystycznych poprzez organizowanie degustacji i spotkań o charakterze kulturowo - edukacyjnym. Wina kalifornijskie postrzegano wowczas jako gorszej jakości niż europejskie, zatem wymagało to ciężkiej pracy, aby zachęcić ludzi do kupna. Zmienito się to w roku 1976, gdy podczas Degustacji Paryskiej' wyroby z Napa Valley zdeklasowały rywali. [2]

Schemat działan amerykańskich winiarzy zaczał przenosić się na kolejne grunty i, w rożnym stopniu, w zależności od lokal- several countries, it has been concluded that a statistical enotourist is a person with income high than average, working on a position requiring high qualifications, and consequently aged $>25$, usu ally between 35 and 45 years of age. Couples or are usually short weekend getaways or longer holidays, during which they visit several locations. Enotourists stay mainly in hotels or residences of good standards, and besides the main attraction which is the winery itself, they are also interested in the local cuisine and the culture of the region. The main motivation of wine tourism is the willingtaste to get to know new wines, the opportunity to well as to discover local traditions their source, as surrounded by the unique vineyard landscape. An unquestionable advantage of enotourism is the fact that the season begins already in early spring, and ends in late autumn, which provides winery owners with all-year-long uniform income [3.

In economic terms, an important aspect of the development of wine tourism is the development of drect sales. According to statistics, even $75 \%$ of tle of wine or other related local products there and ca. $15 \%$ make such purchases again during the next visit or via mail orders. The cost of a bottle in retail sales straight from the manufacturer does no differ from the cost of the same bottle in a store or supermarket, but in the first case the manufacture can earn even twice as much, avoiding margins for distributors and other relevant expenditures [3]. ucts and an attractive location of wineries manding customers, and enotourists certainly are such customers, pay attention to other aspects, such as the aesthetics of the winery, good santary conditions, but also the quality of architecture highlighting the cultural heritage of the region, and the unique climate of the place created by the interior design, illumintion, $\mathrm{music}$, and fragrance [4].

2.2. History and Development of Enotourism in the World

Enotourism is a relatively new branch of tourism. Whilst other forms of holiday, such as trips to beaches, to spas, or to the mountains, have accompanied us for more than a hundred years, United Stan dis the as late as in the 1970s in the received visitors before tharopean wineries had received vistors before that, but the purpose of out touring the vineyard and the region and without learning the secrets of wine production The initial model were actions undertaken in 1975 Napa Valley, California. An organisation associating local wine producers was established there. Its goa was to promote wine and places where it is produced as tourist attractions by organising wine tasing events and cultural - educational meetings. A to European ones, so it required a lot of hard work to encourage people to purchase them. It changed in 1976, when during the Paris Wine Tasting' prod ucts from Napa Valley outclassed their rivals. [2] nego klimatu i uwarunkowan, enoturystyka zaczęła rozwijac się na calym świecie, a przoduja w tym kraje takie jak Francja , Włochy, Hiszpania, Stany Zjednoczone i Argentyna. Ze względu na położenie geograficzne oraz historie turystyka winiarska mocno rozwija się w Europie, a najlepiej rozpowszechniona jest w krajach o bogatej tradycji związanej z produkcja wina - Hiszpanii, Francji, Włoszech. Duży udział maja także Niemcy, Austria, Czechy, Wegry. Ważnymi regionami turystki winnej są tą także kraje Europy południowo-wschodnie - Gie Motdawia gdzie glówna atrakcia turystyczną są whá́n.

wina [1].

Poza Stanami Zjednoczonymi i Europą, enoturystyka rozwinẹła się także w RPA, Nowej Zelandii i Australii. Bardzo mocno wpływa to na rozwój małych przedsiebiorstw winiarskich na przykład, w Nowej Zelandii już $25 \%$ krajowej produkcji wina sprzedawana jest bezpośrednio [1].

2.3. Enoturystyka w Polsce - szanse, potencjał turystyczny W Polsce, biorąc jako kryterium warunki klimatyczne, można wyróżnić 3 główne regiony uprawy winorośli, a co za tym dzie - rozwoju enoturystyki. Pierwszy z nich to zachodni i południowo-zachodnia część kraju, gdzie rzadko występuja temperatury poniżej $-20^{\circ} \mathrm{C}$ ze względu na silny wpływ klimago - daje to możliwośc uprawiania winorosli własciwej. Drugi region to południowa i południowo-wschodnia część Polski, gdzie, przez silniejsze oddziaływanie klimatu kontynentalnego, często występują zimy z temperaturam poniżej $-20^{\circ} \mathrm{C}$, co pozwala jedynie na uprawę bardziej odpornych odmian winorośli. Pozostała część kraju tworzy trzeci region, gdzie, ze względu na niekorzystne warunki klimatyczne, możliwa jest tylko uprawa amatorska z nielicznym wyjątkami [7].

Mimo braku tak sprzyjających warunków klimatycznych, jakie panuja na południu Europy, moda na turystyke winiarska dotarła takie do Polski i roku na rok rozwija sie coraz dyna do niej. Wedlug dostepnych danych taka forme wypoczynku jzz w roku 2009 wybrało ok. 2000 osób a 200-300 osób wzię dzia w orgazoma Ze wisedu ma miej spryjajac Ze wzgędy ij góz tradycj wis 8], m.in.

- tworzenie broszur informacyjnych i portali internetowych o tematyce winiarskiej, gdzie zamieszczone są spisy winnic oraz informacje na temat danego regionu;

- wytyczanie szlakow turystycznych o tematyce winiarskiej np. "Lubuski Szlak Wina i Miodu”, „Podkarpacki Szlak Winnic", „Małopolska Ścieżka Winna";

- organizacja wydarzeń i imprez jednorazowych i cyklicznych takich jak festiwale wina, winobranie, degustacje np. Zielonogórskie Winobranie, Święto Wina w Jaśle;

- tworzenie programów promocyjnych, np. „Paszport Winiarskiego Odkrywcy"

- współpraca z biurami podróży, które umieszczają odwiedziny w winnicach jako jedną z atrakcji organizowanych przez nie wycieczek.
The actions of American winemakers started to get transferred to other areas and, to a different extent, depending on the local climate and conditions, enotourism started to develop globally, with France, Italy, Sp:
tina in the lead.

Due to the geographical location and history, the wine tourism has been developing strongly Europe, and it is most popular in countries with a rich tradition connected with wine production Spain, France, Italy. A great share in the European enotourism is held by Germany, Austria, the Czech Republic, Hungary, too. Important regions of the Whe tourism are also southeast European coundeserving special attention as wines constitute its main tourist attraction. [1]

Besides the United States and Europe, enotourism has also developed in the Republic of South Africa, New Zealand, and Australia. It has a very strong inluence on the development of small wineries, and -for example - in New Zealand already $25 \%$ of the (1)

2.3. Enotorusim in Poland - Opportunities, Tourist Potential

Taking climatic conditions as a criterion, three main vine growing regions can be differentiated in $\mathrm{Po}-$ land, corresponding to the regions of the development of enotourism. The first one is located in we the strong influence of the below $-20^{\circ} \mathrm{C}$ owing fers an opporunity to grow the common grape vine. The second region is the southern and southeastern part of Poland, where - due to the stronger influence of the continental climate - there are ofte winters with temperatures below $-20^{\circ} \mathrm{C}$, which allows to grow only more resistant varieties of vine. The remaining territory of the country constitutes the third region, where due to unfavourable climatic conditions growing vine is possible only on an an(

作 come fashionable in Poland, too, and it has been developing more and more dynamically year after year. According to the available data, such a form of holiday was chosen by ca. 2000 people already in 2009, and $200-300$ tourists took part in organsed enotourist trips [3].

Due to less favourable conditions than in countries ers undertake diversified measures so as to promote and develop their business [8], such as e.g: - Publishing information brochures and internet portals devoted to winemaking, containing lists of wineries and data on a relevant region;

-Demarcating tourist routes organised around the topic of winemaking, e.g. 'Lubuskie Trail of Wine and Honey', 'Podkarpackie Wine Trail, 'Małopolskie Wine Trail';

- Organising one-off and periodical events, such as Wine festivals, grape harvests, wine tastings, e.g. 
Oprócz skupienia się funkcjonalności procesu nie można zapominac o przenikaniu się dwoch stref jakie powinna zawierać winnica - produkcyjnej dla pracowników i turystyczne dla zwiedzających. Dlatego, jeśli w planach jest zapoznanie gości z procesem powstawania wina, cześć wytwórcza powinna być także dopasowana do tych potrzeb - zawierać specjalne przejścia, salki, przeszklenia, a także, szczególnie jeśli chodzi o piwniczke z dojrzewajacymi w beczkach winami - odpowiedni design. Cześć przeznaczona dla zwiedzajacych może być w różnym stopniu rozwinieta - w zabeżn-

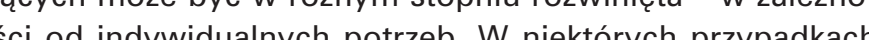
moz zamykć sie ona pa prostej salce degustacyjeji skepie z miejscoc sieni wyrobasi a ewe dulny nocleg i skżewien z zapewhia sa przez lokalne pensjonty, czesto na Won zapew wać wie wspópracy regionaloj. Mozna jednak zanwestowac w kompleksowe zalozienie spe hiaj ce wsayskie potzeby enoturysty whompand restauracje, sale konferencyjne, wystawowe, muzeum, spa inne atrakcje. Wowczas warto też odpowiednio zaprojektować tereny rekreacji na świeżym powietrzu, tak, aby odwiedzający w pełni mogli cieszyć się pięknem otaczającego regionu.

Jeśli chodzi o bryłę i sposób wykonczenia budynku oraz jego detale, warto - także ze względów ekonomicznych - wykorzystać lokalne materiały i formy podkreślając regionalne dziedzictwo i tradycję. Wpisanie budynku w otoczenie buduje niepowtarzalny klimat miejsca i podkreśla poszanowanie naturalnego krajobrazu.

\section{Podsumowanie}

Unikalnym wyzwaniem przy tworzeniu założenia architektoniczno-urbanistycznego, jakim jest winnica niewatpliwie jest połączenie dwóch zadań jakie ma ono spełniać: być jednocześnie dobrze funkcjonującym zakładem produkcyjnym miejscem pracy oraz przestrzenią turystyczno-rekreacyina w której odwiedzający ma wypoczać, zrelaksować się i bez przeszkód odkrywać tajniki produkcii wina oraz czerpać bezdze na temat otaczajacego riogi iz a chitektura i marketing wspótdziaja, a forma, wnetrze iz zagospodarowanie wót budynku firmy znaczaco węrze zagospodarowion wają na jej wizerina wi Nodstawie powyżej opisanych

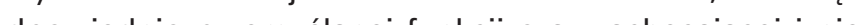
odpowiedio przenyslanej funkcil oraz zachęcajacej i nieaz odważnej formy powstaly zalożenia, kơre przyciągaja nie tylko milośników wina i rekreacjl, ale także pasjonatów architektury.

Jeśli $w$ projekcie uda się spełnić wszystkie te wymagania może powstać obiekt, który będzie zachęcać do odwiedzin równocześnie wspaniałym produktem, jak $\mathrm{i}$ dobrą, funkcjonalną architekturą, co bezpośrednio przekłada się na rozwój enoturystyki.

PRZYPIS

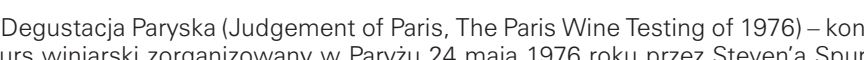
rier, brytyjskiego producenta win, w którym francuscy sedziowie przeprowadzill
dwa . slepe" testy: wina biatego i czerwonego. W obu kategoriach wygraty wina

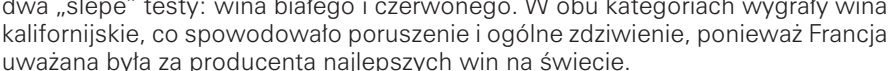

wine production process should be demonstrated to visitors, the production part should also be adjusted to relevant needs - it should be equipped With special passageways, halls, glazed surfaces, The cellar with barrels containing te aging wine. The part addressed to visitors could be developed according to individual needs. In some cases it can be a simple wine tasting room and a shop with the local products, and accommodation and meals could be provided by local guesthouses, often according to the rules of regional cooperation. But, is also possible to invest in a comprehensive projhotel rooms, restaurants, conference halls tion halls, museums, spas, and other attractions. In such a case it is also worth designing outdoor recreational grounds, so that visitors could fully appreciate the beauty of the region.

As far as the very form, finishing, and details of the building are concerned, it is advisable - also for economic reasons - to use local materials an forms, highlighting local heritage and traditions. creates a unique climate of the place and emphasises the respect for the natural landscape.

\section{Summary}

A unique challenge when designing an architectural and urban project of a winery is undoubtedly the combination of two tasks it is supposed to fulfil: to be a well-functioning production plant and workplace, as well as a tourist and recreational space, crets of wine production and gain knowledge on the region surrounding them, without any difficulty. Besides, it is a fact that architecture and marketing cooperate, and that the form, the interiors, and the arrangement of grounds around the building have a significant effect on its appearance. On the basis of the examples of wineries described above, it can be concluded that thanks to a properly conbold, form unique projects were designed, which today attract not only fans of wine and recreation, but also enthusiasts of architecture.

If the designer succeeds in satisfying all these requirements in the project, a facility will be built which will encourage people to spend some time there, with a wonderful product, as well as with

ENDNOTE

Judgement of Paris, or the Paris Wine Testing of 1976

a wine production competition organised in Paris on 24 May which French judges conducted two 'blind' tests: of white
wine, and of red wine. Californian wines won in both cate gories, which caused quite a stir and general surprise, as France had been broadly

BIBLIOGRAPHY

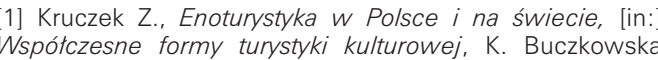
Wspótczesse formy turntyktki kulturowej, K. Buczkowska
i A.M. von Rohrscheidt (ed.). Monograph No. 391, Academy
LITERATURA

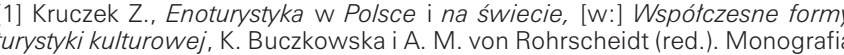
nr 391, AWF Poznan 2009, s. 333-345.

2] Hudin M... Vinologue. Guide to Enotourism, Leavenworth Press, 2014 html (odwiedzone w dniu 23.03.2017r.)

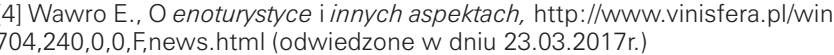
[5] Kapczyński M., Paryż 1976. Szok!!, http:///www.vinisfera.pl/wina, 206, 145, 6] Myśliwiec R., Uprawa winorośli, Plantipress, Kraków, 2009

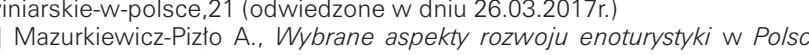
hoczniki Naukowe Stowarzyszenia Ekonomistów Rolnictwa i Agrobiznesu 9] Frearson A. Antinori Winery by Archea Associati, https:I/Mnw.dezeen. Whery / Untaler, hitp. Mww.arch 11] Hotel Marques de Riscal, http: //www.arcspace.com/features/gehry-part 12] Burgess L., How a winery gets designed, https:///vinepair.com//wine-blog/

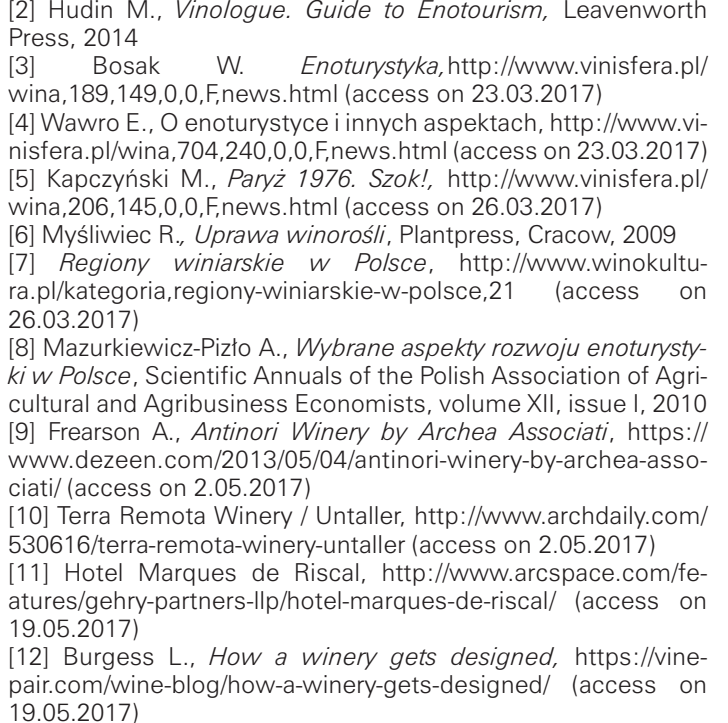

